\title{
Fungsi Musik Dayak Kanayatn
}

\author{
Amir Razak ${ }^{1}$ \\ Ferdinand $^{2}$ \\ ${ }^{1}$ Staf Pengajar Jurusan Etnomusikologi Institut Seni Indonesia Yogyakarta \\ ${ }^{2}$ Praktisi Seni Kalimantan Barat
}

\begin{abstract}
Abstrak
Musik Dayak Kanayatn dalam aspek antro-sosio mengalami penggandaan fungsi yang disebabkan sublimasi intra-esktra musikal lokal jenius dan kebutuhan masyarakat, dimana sampai saat ini deskripsi mengenai musik etnis, terutama Dayak Kanayatn masih belum banyak dijelaskan dalam konteks kebudayaan, sehingga penelitian ini fokus dalam mendeskripsikan fungsi musik Dayak Kanayatn dalam aktifitas masyarakat

Kualitatif naratif adalah upaya menggambarkan proses atau fungsi musik Dayak Kanayatn sehingga dapat memberikan intepretasi sesuai fakta di masyarakat, dimana pengumpulan data adalah dengans studi pustaka, observasi dan dokumentasi sedangkan analisa data mengunakan teknik intepretasi domain.

Hasil penelitian menunjukkan bahwa musik Dayak Kanayatn mempunyai beberapa fungsi antara lain; sarana hiburan, komodifikasi wisata, pengesahan lembaga sosial, integrasi kelompok sosial, media propaganda, indentitas budaya lokal, sarana pendidikan informal.
\end{abstract}

Kata kunci : Fungsi musik, Dayak Kanayatn

Abstract

Kanayatn Dayak music in the anthro-social aspect experienced a multiplication of functions caused by sublimation of local musical genius intra-extras and the human needs of the community, where until now the description of ethnic music, especially Dayak Kanayatn is still not widely explained in the cultural context, so this research focuses on describing functions of Dayak kanayatn music in community activities.

Qualitative narrative is an effort to describe the process or function of Dayak Kanayatn music so that it can provide interpretation in accordance with facts in the community, where data collection is through literature study, observation and documentation while data analysis uses domain interpretation techniques.

The results showed that Dayak Kanayatn music had several functions including; entertainment facilities, commodification of tourism, ratification of social institutions, integration of social groups, propaganda media, local cultural identity, informal education facilities.

Keywords: Music function, Dayak Kanayatn 


\section{Pendahuluan}

Musik etnis yang tersebar di seluruh Indonesia pada hakekatnya memiliki fungsi dan tujuan yang hampir sama, tetapi berbeda pada pola penyajiannya karena dipengaruhi oleh faktor lokal jenius yang bertindak dan bertingkah laku dalam mensublimasi intramusikal dan ekstramusikal sebuah musik.

Kemampuan lokal jenius dalam mensublimasikan nilai intra-ekstra musical memberikan pengaruh dalam fungsi musik dalam berbagai aktifitas masyarakat, dimana nilai gunanya tidak bersifat tunggal melainkan mengalami percabangan atau penggandaan peran, seperti musik Dayak Kanayatn yang mempunyai beberapa fungsi dalam aktifitas masyarakat.

Fungsi menurut Malinnowsky (dalam Koentjaraningrat: 1987) memberikan penjelasan bahwa segala sesuatu yang ada di dunia ini memiliki fungsi. Fungsi berarti memiliki kontribusi yang dapat diberikan kepada yang lain, sedangkan Merton (dalam Kaplan dan Manners: 2011) menerangkan bahwa (1) postulat keutuhan fungsional masyarakat mempunyai arti bahwa segala sesuatu berhubungan dengan fungsional dengan segala sesuatu yang lain, (2) Postulat fungsionalisme universal bahwa segala unsur budaya melaksanakan suatu fungsi dan tidak ada satupun unsur lain yang mampu melaksanakan fungsi yang sama. Budaya tidak terintegrasi secara sempurna atau dapat terintegrasi dalam tatarantataran tertentu. Berbagai unsur budaya dapat melakukan suatu fungsi yang sama (alternatif fungsional). dalam upaya menjernihkan konsepnya maka Merton menambahkan adanya oposisi biner fungsi latens dan manifest mengenai konsekuensi obyek ihwal kebudayaan yang dikehendaki dan ditolak oleh masyarakat.

Fungsional Malinowsky dan Merton memberikan gambaran bahwa peran musik Dayak Kanayatn merupakan obyek material yang cukup menarik, dimana perlu pendefinisian mengenai percabangan fungsinya dalam aktifitas masyarakat sehinnga nantinya dapat mendeskripsikan beberapa fungsinya berdasarkan pendekatan formal antro-sosio kultural. 


\section{Fungsi Musik Alan P. Meriam}

Meriam (1976: 219-226)

memberikan uraian singkat tentang fungsi musik yang merupakan faktor penting dalam etnomusikologi terutama mempelajari tingkah laku manusia karena ketika kita berbicara mengenai nilai guna music maka kita akan berbicara mengenai peran music dalam kehidupan sosial kemasyarakatan, lingkungan ataupun yang berhubungan dengan aktifitas. Berdasarkan faktor itu maka Meriam menjelaskan tentang 10 fungsi music antara lain, (1) sebagai ekspresi emosional, (2) kepuasan estetis, (3) sarana hiburan, (4) sarana komunikasi, (5) persembahan simbolis, (6) respon fisik, (7) pengukuhan institusi sosial dan upacara keagamaan, (8) kelangsungan dan kestabilan budaya, (9) pengukuhan norma masyarakat, (10) integritas masyarakat.

\section{Metode Penelitian}

Adanya fungsi musik Dayak Kanayatn yang bersifat ganda memberikan gagasan bahwa penelitian ini menggunakan kualitatif naratif karena untuk memberikan penjelasan tentang beberapa fungsi musik Dayak Kanayatn dalam aktifitas masyarakat. Studi pustaka, observasi dan dokumentasi menjadi teknik pengumpulan data sedangkan analisis data menggunakan teknik intepretasi domain sehingga mampu memberikan uraian tentang fungsi musik dayak Kanayatn dalam konteks kebudayaan.

\section{Hasil dan Pembahasan}

Deskripsi Meriam mengenai 10 fungsi musik, konsep fungsional Malinowsky dan Merton dalam konteks kebudayaan atau aktifitas masyarakat memberikan sebuah intepretasi bahwa sesungguhkan dalam sebuah obyek penelitian, khususnya musik Dayak Kanayatn dalam tinjauan antro-sosio menunjukkan bahwa perannya dalam kehidupan masyarakat ada beberapa fungsi antara lain:

1) Sarana hiburan

Musik Dayak Kanayatn yang dimainkan dalam upacara peralihan tingkat kehidupan seseorang berfungsi sebagai hiburan karena mempunyai tujuan sebagai ekspresi kegembiraan dan menghibur penonton. Hiburan merupakan kebutuhan 
hidup manusia yang sangat penting, karena dengan hiburan manusia dapat meringankan beban dari tekanan-tekanan sebagai efek ketegangan psikologis maupun fisik yang banyak dijumpai dari berbagai kehidupan. Segala macam hiburan tersebut kebanyakan berkaitan dengan seni seperti seni musik.

Seni dan hiburan merupakan nagian yang tidak terpisahkan dengan kehidupan manusia. Kebuthan akan hiburan tersebut beragam, dari yang biasasampai kontemporer. Hal ini karena jiwa dan kenyakinan masyarakat berbeda beda, maka sudah tentu corak, ragam, bventuk dan hiburannya berbeda pula sesuai dengan lingkungan masyarakatnya.

\section{2) Komodifikasi seni wisata}

Pertumbuhan pariwisata di beberapa daerah dianggap sangat menguntungkan dan dapat dijadikan penunjang perkembangan ekonomi masyarakat dan daerah. Kebutuhan manusia akan kesenian memberikan peluang terjadinya komodifikasi, dimana nilai tukar dan ekonomis dari sebuah produk kesenian mempunyai dampak biner terhadap kemajuan industri pariwisata tetapi juga menghilangkan proses nilai dan kedalaman maknanya.

Sebagai kemasan seni wisata, musik dayak kanayatn mempunyai beberapa ciri yaitu (1) mimesis atau tiruan dari aslinya, (2) bentuk peertunjukkannya lebih padat dan singkat, (3) Variatif, (4) Profan, (5) murah harganya. Perubahan ini terjadi karena kebutuhan akan seni pertunjukkan yang singkat dan bersifat sementara.

Sajian seni wisata musik Dayak Kanayatn memerlukan ruang dan waktu seoptimal mungkin sehingga nilai estetis dan menarik untuk tujuan pertunjukkan harus tetap mengutamakan aspek lokal jenius yang mengandung nilai lihur dan adiluhung sehingga nantinya dapat menjadi budaya lokal yang menunjang budaya nasional yang berbasis pada seni tradisi.

\section{3) Pengesahan lembaga sosial}

Suatu upacara tidak hanya dilakukan untuk peringatan tingkat kehidupan atau memperingati waktuwaktu tertentu, namun dilakukan pula untuk memulai suatu pekerjaan. Fakta ini menunjukkan bahwa upacara bertujuan untuk mendapatkan berkah dan 
keselamatan dari perkerjaan tersebut. Dalam setiap upacara atau kegiatan masyarakat, musik dayak Kanayatn selalu menjadi pilihan utama sebagai iringan untuk menjadi sahnya suatu pekerjaan. Bahkan kalau tidak dilaksanakan akan menimbulkan efek negatif bagi masyarakat

\section{4) Integrasi kelompok sosial}

Irama musik Dayak Kanayatn juga berfungsi sebagai pengikat solidaritas kelompok, terutama bagi orang-orang yang tergabung dalam kelompok kesenian. Seringnya bertemu pada jadwal latihan atau pementasan membuat terjalinnya hubungan kekeluargaan dan merasa saling membutuhkan antar anggota kelompok, terdapat pula orang-orang yang berkumpul saat latihan berlangsung untuk menikmati irama musik dayak Kanayatn. Mereka dating dengan tujuan mengisi waktu luang atau hanya sekedar mendengarkan keindahan musik tersebut (menghibur diri). Melalui kegiatan tersebut akan tercipta sebuah kedekatan emosional yang akhirnya mengarah kepada terciptanya rasa kebersamaan, keakraban sebagai wujud integtasi kelompok sosial suatu masyarakat

\section{5) Media Propaganda}

Salah satu fungsi seni pertunjukkan adalah sebagai untuk mendidik mental dan moral karena seni pertunjukkan, khususnya seni tradisi dianggap salah satu cara yang ampuh dalam menggarap potensi karakteristiknya yang dianggap mampu menyampaikan ide atau pesan yang sangat efektif,misalnya seperti beberapa kelompok seni tradisi yang terkait dengan pihak sponsor.

Pihak sponsor sebagai modal ekonomi biasanya dating dari seseorang yang mempunyai kedudukan tinggi dalam sebuah arena yang ingin mempromosikan usaha atau produk mereka, tidak menutup kemungkinan datang dari partai politik. Melalui kesenian mereka melakukan propaganda untuk kepentingan pribadi.

Musik dayak kanayatn merupakan salah satu yang sering dipergunakan dalam hal propaganda, mereka mencoba melegitimasi dengan menyampaikan pesan-pesan kepada konsumen atau audiens.

Mengadopsi Merton mengenai oposisi biner fungsi latens dan manifest maka sebenarnya fungsi musik dayak kanayatn sebagai media propaganda merupakan fungsi latens karena bagi 
masyarakat peran musik dayak Kanayatn sebagai media propaganda tidak sesuai atau tidak dikehendaki dalam ihwal kebudayaan masyarakat, tetapi secara fakta fungsi latens ini mampu berubah menjadi fungsi manifest karena adanya kebutuhan manusia (human needs) yang berdasarkan prinsip komodifikasi produk budaya bermotif nilai tukar dan nilai ekonomis, hanya saja nilai sakral menjadi berubah karena unsur profane yang dikedepankan.

6) Identitas Budaya Lokal

Kehadiran musik Dayak Kanayatn dapat menjadi identitas budaya lokal karena tumbuh dan berkembangnya suatu kesenian tidak terlepas dari peran masyarakat pemiliknya. Perkembangan itu sejalan dengan kontruksi intelektualitas dan kreatifitas masyarakat yang akhirnya akan membuahkan ciri khas tersendiri sesuai budaya yang melingkupinya, seperti apa yang disampaikan Umar Kayam:

Nilai-nilai tradisional yang tumbuh dalam seni pertunjukkan di wilayah Asia Tenggara umumnya merupakan bagian kebudayaan masyarakat, dengan demikian mengandung sifat-sifat yang khas dari masyarakatnya pula. Secara umum mempunyai ciri khas, (1) nilai-nilai estetik mempunyai batasan pada kultur yang menunjangnya, (2) nilai estetis berkembang secara perlahan lahan sesuai sifat masyarakatnya, (3) nilai estetik merupakan bagian dari kosmos kehidupan yang bulat tidak terbagi-bagi, patron kotak, (4) nilai estetis terbentuk dari kesadaran kolektif masyarakat. Meskipun ada karya seni yang tercipta karena individu, tetapi biasanya dianggap sebagai karya kolektif dan mengalami perkembangan kolektif juga.

\section{7) Pendidikan Informal}

Irama musik Dayak Kanayatn banyak mengandung unsur-unsur budaya lokal dan nilai lihur masyarakat menyangkut kehidupan seperti kebaikan dan kebenaran. Mempelajari seni tradisi berarti memperkaya diri dengan nilai luhur dan dapat menghaluskan budi pekerti sebagai penangkal sifat buruk pada batin manusia. Hal ini karena seluruh kesenian tradisi mengandung nilai luhur dan falsafah hidup yang berpegang pada adat dan kebenaran hakiki sesuai dengan harkat dan martabat bangsa 


\section{Simpulan}

Penelitian menunjukkan bahwa

fungsi musik Dayak Kanayatn adalah sebagai sarana hiburan, komodifikasi wisata, pengesahan lembaga sosial, integrasi kelompok sosial, media propaganda, identitas budaya lokal dan pendidikan informal.

\section{Daftar Pustaka}

Cresswell, John. 2010. Research Design, Pendekatan Kualitatif, Kuantitatif dan Mixed, terjemahan: Yogyakarta. Pustaka Pelajar.

Meriam, Alan. P . 1976. The Anthropology of Music. USA: University Press, Sixth Printing.

Kayam, Umar. 2002. Seni, Tradisi, Masyarakat, seperti yang dikutip Agus Sachari dalam bukunya Estetika, Makna, Simbol dan Daya. Bandung: Institut Teknologi Bandung.

Kaplan, David dan Manners, Robert. 2011. Teori budaya, terjemahan Landung Simatupang: Yogyakarta. Pustaka Pelajar.

Koentjaraningrat. 1987. Sejarah Teori Amtropologi: Jakarta. UI Press

Razak, Amir et al. 2006. Laporan Penelitian Eksistensi Genre Musik Etnis di Indonesia. Program Hibah Kompetisi A-2 Jurusan
Etnomusikologi FSP Institut Seni Indonesia Yogyakarta. 